\title{
Research needs in nuclear decommissioning: an analysis based on stakeholders' points of view
}

\author{
Simone Müller ${ }^{1}$, Muhammad Junaid Ejaz Chaudhry ${ }^{1}$, Angelika Bohnstedt ${ }^{1}$, Sascha Gentes ${ }^{1}$, \\ Christine Georges ${ }^{2}$, Laura Aldave De Las Heras ${ }^{3}$, Emilio Garcia Neri ${ }^{4}$, Anthony Banford ${ }^{5}$, and \\ Kurt Van Den Dungen 6 \\ ${ }^{1}$ Karlsruhe Institute of Technology (KIT), Karlsruhe, Germany \\ ${ }^{2}$ Commissariat à l'Energie Atomique et aux Energies Alternatives (CEA), Marcoule, France \\ ${ }^{3}$ Joint Research Centre (JRC), European Commission, Karlsruhe, Germany \\ ${ }^{4}$ Empresa Nacional de Residuos Radiactivos (ENRESA), Madrid, Spain \\ ${ }^{5}$ National Nuclear Laboratory (NNL), Workington, UK \\ ${ }^{6}$ Centre d'étude de l'énergie nucléaire (SCK-CEN), Brussels, Belgium \\ Correspondence: Simone Müller (simone.mueller@kit.edu) \\ Published: 10 November 2021
}

\section{English version}

\subsection{Introduction}

Decommissioning of nuclear facilities is a multidiscipline project, including all technical and management actions associated with the terminated operation of a nuclear installation and its subsequent dismantling to remove it from regulatory control while delivering an environmentally friendly end-product. In 2016, the European Commission was convinced that more commitment was needed to develop and to use research and innovation in decommissioning projects and to promote and organise at international level the cofinancing of developments by stakeholders with common objectives. This resulted in the funding of a Coordination and Support Action project called "SHARE" (StakeHolders based Analysis of REsearch for decommissioning), within the framework of the EU-Horizon 2020 nuclear research program. The objective of this project is the development of a Strategic Research Agenda (SRA) associated with a roadmap for the next 10-15 years, to increase confidence in the decommissioning process. It also aims to encourage the future coordination of research topics that are recommendable for financing in the next decade. Moreover, it will facilitate access to expertise and technology and maintain competences in decommissioning and environmental remediation for the benefit of member states in Europe and beyond.

\subsection{The analysis}

The SHARE project intends to provide an inclusive roadmap for research in decommissioning, in technical and nontechnical areas, enabling stakeholders to jointly improve safety, reduce costs and minimise environmental impact in the decommissioning of nuclear facilities. It is based on a broad analysis of stakeholder needs including R\&D, R\&I, education, training, regulations, legislation, project management, costing and standardisation.

A detailed survey divided into different thematic areas of nuclear decommissioning (e.g. safety and radiological protection aspects, decommissioning material and radioactive waste management, cost estimation and benchmarking) was sent to 650 stakeholders throughout the evaluation chain, to obtain their opinions about importance and urgency of their respective research needs. Similarly, an elaborate literature review was carried out, highlighting existing methodologies and techniques as well as international initiatives in these thematic areas. The SHARE project is built on a consultation process including the needs and point of views of different stakeholders. In this respect, two online workshops were organised to receive stakeholders' valuable opinions by firstly investigating with them issues, challenges, and opportunities in research and secondly sharing status and results of ongoing developments (SHARE consortium, 2020a, b).

A gap analysis between needs identified in the survey and at the workshops, and existing solutions or on-going developments drawn from the literature review was carried out. 
The first outcome of the investigation was presented at the DigiDecom 2021 conference, where participants gave feedback (SHARE consortium, 2021). The final analysis provided actions that can impact identified needs. The compiled actions will be further analysed and grouped as key research topics, which will be the basis for the SRA and the roadmap. This may also lead to better future harmonisation in research of technological approaches used in decommissioning.

\subsection{Conclusion}

One of the main added values of the SHARE project is to collect the opinion of the global stakeholders decommissioning community, in order to know and understand the issues and challenges they are facing and deficits or opportunities they have in mind. As a result, SHARE will provide a SRA and a roadmap that will support policymakers in their choice of areas, eligibility for financial contribution and for potential future collaborative research projects in R\&D, R\&I, methodologies, standardisation in technical and non-technical areas.

\section{More information at:}

linkedin/group SHARE Road map for Decommissioning, https://www.linkedin.com/company/share-h2020-project (last access: 5 November 2021) and https://share-h2020.eu/ (last access: 5 November 2021).

\section{Deutsche Version}

\subsection{Einleitung}

Die Stilllegung von kerntechnischen Anlagen ist ein Projekt unter Einbezug vieler Fachrichtungen, einschließlich sämtlicher technischer und organisatorischer Maßnahmen, die mit der Beendigung des Betriebs einer kerntechnischen Anlage und ihrer anschließenden Demontage einhergehen, mit dem Ziel, die behördliche Kontrolle darüber aufzuheben und gleichzeitig ein umweltfreundliches Endprodukt zu liefern. Im Jahr 2016 war die Europäische Kommission davon überzeugt, dass mehr Engagement nötig war, um Forschung und Innovationen in Stilllegungsvorhaben $\mathrm{zu}$ entwickeln und anzuwenden sowie die Kofinanzierung von Beteiligten mit gemeinsamen Zielen auf internationaler Ebene zu fördern und zu organisieren. Das führte zur Finanzierung eines Koordinierungs- und Unterstützungsmaßnahmenprojekts mit der Bezeichnung „SHARE“ (,StakeHolders based Analysis of REsearch for decommissioning ") im Rahmen des EU-Nuklearforschungsprogramms Horizon 2020. Das Ziel dieses Projekts besteht in der Entwicklung einer strategischen Forschungsplanung (,Strategic Research Agenda“, SRA) zusammen mit einem Fahrplan für die nächsten 10-15 Jahre, um das Vertrauen in den Stilllegungsprozess zu erhöhen; ein weiteres Ziel ist die Förderung der künftigen Koordinierung von Forschungsthemen, die für die Finanzierung im nächsten Jahrzehnt empfehlenswert sind. Außerdem wird es den Zugang zu Expertise und Technologien erleichtern und Kompetenzen für die Stilllegung und Umweltsanierung zum Nutzen der Mitgliedsstaaten in Europa und darüber hinaus erhalten.

\subsection{Analyse}

Ziel des SHARE-Projekts ist es, einen umfassenden Fahrplan für die Stilllegungsforschung in technischen und in nichttechnischen Bereichen zu erstellen, der die Beteiligten in die Lage versetzt, gemeinsam die Sicherheit zu verbessern, die Kosten zu reduzieren und die Auswirkungen auf die Umwelt bei der Stilllegung der kerntechnischen Anlagen zu minimieren. Er basiert auf einer umfassenden Auswertung der Bedürfnisse der Beteiligten einschließlich Forschung und Entwicklung (R\&D), Forschung und Innovation (R\&I), Bildung, Schulung, Vorschriften, Gesetzgebung, Projektmanagement, Kostenrechnung und Standardisierung, u. a.

Ein detaillierter Überblick mit Aufteilung in verschiedene thematische Bereiche des nuklearen Rückbaus (z.B. Sicherheits- und Strahlenschutzaspekte, Entsorgung von Rückbaumaterial und radioaktiven Abfällen, Kostenschätzung und Benchmarking) wurde an 650 Beteiligte im Verlauf der gesamten Wertschöpfungskette versandt, um ihre Meinung bezüglich der Bedeutung und Dringlichkeit des jeweiligen Forschungsbedarfs einzuholen. In ähnlicher Weise wurde eine ausführliche Literaturrecherche durchgeführt, in der vorhandene Methoden und Techniken sowie internationale Initiativen in diesen Themenbereichen herausgestellt wurden. Das SHARE-Projekt beruht auf einem Beratungsprozess unter Einbeziehung der Bedürfnisse und Standpunkte der verschiedenen Beteiligten. Diesbezüglich wurden 2 Online-Workshops organisiert, um die wertgeschätzten Meinungen der Beteiligten zu erfahren, indem erstens die Fragen, Herausforderungen und Möglichkeiten der Forschung gemeinsam mit ihnen untersucht wurden und zweitens Stand und Ergebnisse laufender Entwicklungen ausgetauscht wurden (SHARE consortium, 2020a, b).

Eine Defizitanalyse zwischen Bedürfnissen, wie in der Erhebung und den Workshops ermittelt, und vorhandenen Lösungen oder laufenden Entwicklungen, wie in der Literaturrecherche erhoben, wurde durchgeführt. Die ersten Ergebnisse der Untersuchung wurden auf der DigiDecom2021-Konferenz präsentiert, bei der die Teilnehmer ein Feedback gaben (SHARE consortium, 2021). Die abschließende Auswertung zeigte Maßnahmen auf, die einen Einfluss auf die ermittelten Bedürfnisse haben können. Die zusammengestellten Maßnahmen werden weiter ausgewertet und als zentrale Forschungsthemen gruppiert, was die Grundlage für die SRA und den Fahrplan darstellen wird. Das führt möglicherweise auch zu einer besseren zukünftigen Harmonisierung bei der Erforschung technologischer Ansätze, die bei der Stilllegung eingesetzt werden. 


\subsection{Schlussfolgerung}

Ein wesentlicher Zusatznutzen des SHARE-Projekts besteht darin, die Meinung der globalen Gemeinschaft der Interessengruppen für die Stilllegung einzuholen, um die Fragen und Herausforderungen zu kennen und zu verstehen, vor denen sie stehen, und die Defizite und Möglichkeiten, die ihnen vorschweben. Daher wird SHARE eine SRA und einen Fahrplan bereitstellen, der die politischen Entscheidungsträger bei der Auswahl ihrer Bereiche unterstützt, die sich für eine finanzielle Beteiligung und für potenzielle zukünftige Kooperationsforschungsprojekte in $R \& D, R \& I$, Methodologie, Standardisierung in technischen und nichttechnischen Bereichen eignen.

Financial support. This research has been supported by the Horizon 2020 (grant no. SHARE (847626)).

\section{References}

SHARE consortium: SHARE organized a 2-days workshop on international best-practices in nuclear Decommissioning - Share, available at: https://share-h2020.eu (last access: 5 November 2021), 2020a.

SHARE consortium: https://share-h2020.eu/2020/12/09/317people-registered-to-the-public-online-workshop-organized-byshare-consortium-1-3-december-2020/ (last access: 5 November 2021), 2020 b.

SHARE consortium: Synergy with DigiDecom 2021 for a step further towards SHARE Strategic research agenda - Share, available at: https://share-h2020.eu/2021/03/30/synergy-withdigidecom-2021-for-a-step-further-towards-share,-strategicresearch-agenda/ (last access: 5 November 2021), 2021. 